\title{
PENGARUH VARIASI KONSENTRASI NaOH PADA ZEOLIT ALAM LAMPUNG TERHADAP PRODUK SILIKA
}

\section{THE EFFECT OF VARIATION OF NaOH CONCENTRATION ON LAMPUNG NATURAL ZEOLIT ON SILICA PRODUCTS}

\author{
Syafriadi ${ }^{1}$, Siti Marhamah' ${ }^{1}$, Muhammad AI Muttaqii ${ }^{2 *}$ \\ ${ }^{1}$ Jurusan Fisika, Fakultas MIPA, Universitas Lampung, Bandar Lampung, 35141, Indonesia \\ ${ }^{2}$ Pusat Riset Kimia, Badan Riset dan Inovasi Nasional (BRIN), Kawasan PUSPIPTEK Serpong, \\ Tangerang, 15314, Indonesia \\ *Email: almuttaqiimuhammad@gmail.com
}

Diterima : $08-04-2021 \quad$ Direvisi : $08-09-2021 \quad$ Disetujui : $22-12-2021$

\begin{abstract}
ABSTRAK
Zeolit alam merupakan Kristal alumino silikat dengan struktur kerangka tiga dimensi yang dibentuk oleh tetrahedral alumina ( $\mathrm{AlO}_{4}^{5-}$ ) dan silika ( $\mathrm{SiO}_{4}^{4-}$ ). Proses produksi silika pada zeolit alam dilakukan melalui metode sol-gel dengan penambahan larutan $\mathrm{NaOH}$. Penelitian ini bertujuan mengetahui variasi konsentrasi larutan $\mathrm{NaOH}$ dan zeolit alam terhadap produk silica melalui proses sol-gel. Metode produk sisilika dilakukan dengan membuat larutan $\mathrm{NaOH}$ dengan variasi konsentrasi $0,2 \mathrm{M}, 0,4 \mathrm{M}, 0,6$ M, 0,8 M, dan 1 M. Zeolit alam divariasikan dengan massa $15 \mathrm{gr}, 30 \mathrm{gr}$ dan $45 \mathrm{gr}$. Hasil produk silica terbaik diperoleh pada konsentrasi $\mathrm{NaOH} 1 \mathrm{M}$ dan massa zeolit alam $15 \mathrm{gr}$ dengan persentase 97,738 $\%$. Kandungan senyawa kimia dalam setiap produk silica didominasi $\mathrm{SiO}_{2}$. Fasa yang terbentuk pada produk silica didominasi oleh fasa tridymite $\left(\mathrm{Si}_{24.00} \mathrm{O}_{48.00}\right)$, Cristobalite $\left(\mathrm{Si}_{4.00} \mathrm{O}_{8.00}\right)$, Coesite $\left(\mathrm{Si}_{16.00} \mathrm{O}_{32.00}\right)$, Moganite $\left(\mathrm{Si}_{12.00} \mathrm{O}_{24.00}\right)$, Quartz $\left(\mathrm{Si}_{3.00} \mathrm{O}_{6.00}\right)$ dan Stishovite $\left(\mathrm{Si}_{2.00} \mathrm{O}_{4.00}\right)$.
\end{abstract}

Kata kunci: $\mathrm{NaOH}$, zeolite alam, silika

\begin{abstract}
Natural zeolites are alumina tetrahedral $\left(\mathrm{AlO}_{4}^{5-}\right)$ and silica ( $\mathrm{SiO}_{4}^{4-}$ ) with aluminosilicate crystals with a three-dimensional framework structure. The production process of silica in natural zeolite was carried out through the sol-gel method with $\mathrm{NaOH}$ solution. This study aims to determine the concentration variations of $\mathrm{NaOH}$ and natural zeolite solutions on silica products through the sol-gel methods. The silica production method was carried out by making $\mathrm{NaOH}$ solution with various concentrations of 0,2 $\mathrm{M}, 0,4 \mathrm{M}, 0,6 \mathrm{M}, 0,8 \mathrm{M}$, and $1 \mathrm{M}$. Natural zeolite was varied with masses of $15 \mathrm{gr}, 30 \mathrm{gr}$, and $45 \mathrm{gr}$. The best silica product results were obtained at a concentration of $1 \mathrm{M} \mathrm{NaOH}$ and a mass of $15 \mathrm{gr}$ natural zeolite with a percentage of $97,738 \% . \mathrm{SiO}_{2}$ dominates the chemical compound content in each silica product. The phases formed in the silica product are dominated by tridymite $\left(\mathrm{Si}_{24.00} \mathrm{O}_{48.00}\right)$, Cristobalite $\left(\mathrm{Si}_{4.00} \mathrm{O}_{8.00}\right)$, Coesite $\left(\mathrm{Si}_{16.00} \mathrm{O}_{32.00}\right)$, Moganite $\left(\mathrm{Si}_{12.00} \mathrm{O}_{24.00}\right)$, Quartz $\left(\mathrm{Si}_{3.00} \mathrm{O}_{6.00}\right)$ and Stishovite $\left(\mathrm{Si}_{2.00} \mathrm{O}_{4.00}\right)$.
\end{abstract}

Keywords: $\mathrm{NaOH}$, natural zeolit, silica

\section{INTRODUCTION}

7 eolit merupakan bahan galian nonlogam atau mineral industri multiguna karena memiliki sifat-sifat fisika dan kimia yang unik sebagai penyerap, penukar ion, penyaring molekul dan katalisator (Purnamasari, 2015). Zeolit merupakan suatu mineral yang terdiri atas kristal alumina silikat terhidrasi yang mengandung kation alkali atau alkali tanah dalam kerangka tiga dimensi. Ion-ion alkali tersebut dapat diganti oleh kation 
lain tanpa merusak struktur zeolit. Pemanfaatan zeolit umumnya berdasar pada porositas tinggi, muatan di permukaan, keberadaan kation-kation tukar, serta jumlahnya yang melimpah di alam. Zeolit terbagi atas dua jenis berdasar asalnya yaitu zeolit alam dan zeolit sintetik. Zeolit sintetis lebih sering digunakan untuk kepentingan komersial dibandingkan dengan zeolit alam, hal ini dikarenakan keseragaman ukuran partikel dan tingkat kemurnian yang tinggi pada zeolit sintetis (Sugiarti et al., 2017).

Lampung sendiri memiliki sumber zeolit alam yang sangat melimpah. Data yang bersumber dari Direktorat Pengembangan Potensi Daerah tahun 2012 menyatakan bahwa potensi sumber daya alam zeolit yang ada di Lampung berkisar 31.173.505 ton. Kandungan silika dan alumina dari zeolit alam Lampung ini sangat potensial untuk dimanfaatkan sebagai bahan baku pengganti silika dan alumina komersil (Ginting et al., 2019). Hampir seluruh endapan zeolit yang ditemukan di Indonesia tersusun oleh mineral klinoptilolit, mordenit atau campuran keduanya, terkadang sedikit mengandung mineral heulandit. Disamping mengandung mineral tersebut zeolit juga mengandung mineral pengotor seperti kwarsa, plagioklas, montmorilonit, pirit, kaolin dan lain-lain. Warna bahan galian zeolit beraneka ragam antara lain hijau, putih kehijauan, putih merah daging, coklat abu-abu kebiruan dan lainnya bergantung dengan kondisi lingkungan yang mempengaruhinya (Dur, 2017). Komposisi penyusun zeolit alam lampung ditunjukkan pada Tabel 1.

Tabel 1. Hasil analisis XRF zeolit alam lampung(Ginting et al., 2019).

\begin{tabular}{cc}
\hline Komposisi & Konsentrasi $(\%)$ \\
\hline $\mathrm{Al}_{2} \mathrm{O}_{3}$ & 15,815 \\
$\mathrm{SiO}_{2}$ & 79,046 \\
$\mathrm{~K}_{2} \mathrm{O}$ & 1,813 \\
$\mathrm{CaO}$ & 1,401 \\
$\mathrm{MnO}$ & 0,018 \\
$\mathrm{Fe}_{2} \mathrm{O}_{3}$ & 1,157 \\
$\mathrm{Rb}_{2} \mathrm{O}$ & 0,008 \\
$\mathrm{SrO}$ & 0,024 \\
$\mathrm{Y}_{2} \mathrm{O}_{3}$ & 0,002 \\
$\mathrm{ZrO}_{2}$ & 0,013 \\
$\mathrm{Ag}_{2} \mathrm{O}$ & 0,184 \\
$\mathrm{BaO}^{\mathrm{Eu}}$ & 0,045 \\
$\mathrm{Cl}_{3}$ & 0,009 \\
\hline
\end{tabular}

Zeolit tanpa aktivasi memiliki kemampuan adsorpsi yang rendah karena sebelum diaktivasi luas permukaan lebih kecil. Luas permukaan yang kecil ini diakibatkan karena masih sedikitnya pori-pori yang terbentuk pada permukaan zeolit. Selain itu, pori-pori tersebut masih tertutup oleh zat pengotor (Pratomo et al., 2017). Pengaruh asam adalah cara yang efektif untuk mengatur rasio $\mathrm{SiO}_{2}$ atau $\mathrm{Al}_{2} \mathrm{O}_{3}$ dari zeolit alam. Tes ortogonal dirancang untuk mengoptimalkan pengolahan kondisi asam. Konsentrasi asam, waktu dan perlakuan suhu digunakan untuk mengatur secara kuantitatif rasio $\mathrm{SiO}_{2}$ atau $\mathrm{Al}_{2} \mathrm{O}_{3}$ dari zeolit alam. Faktor primer dan sekunder dari pengolahan asam adalah waktu perlakuan asam, konsentrasi asam dan suhu asam. Konsentrasi asam, waktu dan suhu yang digunakan dapat secara efektif mengatur luasnya dealuminasi rasio $\mathrm{SiO}_{2}$ atau $\mathrm{Al}_{2} \mathrm{O}_{3}$ dari zeolit alam. Zeolit yang diolah dengan asam disiapkan dengan rasio $\mathrm{SiO}_{2}$ atau $\mathrm{Al}_{2} \mathrm{O}_{3}$ yang berbeda, diatur oleh konsentrasi asam yang memiliki luas permukaan spesifik yang lebih tinggi, volume mikropori, kandungan gugus silanol dan hidrofobisitas (Wang et al., 2019). Zeolit alam dengan komposisi yang berbeda dimodifikasi dengan larutan natrium hidroksida ( $\mathrm{NaOH})$. Perlakuan dengan $\mathrm{NaOH}$ menyebabkan penurunan luas permukaan dan mikroporositas serta kerusakan sebagian struktur zeolit yang tergantung pada komposisi zeolit. Perlakuan $\mathrm{NaOH}$ 
menghasilkan peningkatan kapasitas adsorpsi (Ates, 2018). Zeolit memiliki muatan negatif akibat subtitusi ion $\mathrm{Al}^{3+}$ terhadap $\mathrm{Si}^{4+}$ dalam struktur jaringannya dapat dinetralkan dengan ion alkali atau alkali tanah. Karena pertimbangan tersebut maka dilakukan sintesis zeolit untuk memperoleh silika menggunakan metode sol gel (Sugiarti et al., 2017).

Sol gel merupakan suatu istilah yang umum digunakan untuk menggambarkan preparasi material keramik melalui beberapa tahapan yang meliputi pembuatan sol, gelasi sol, dan penghilangan fasa cair. Metode sol-gel merupakan metode yang digunakan untuk membuat suatu material padat dari nonopartikel atau molekul yang berukuran kecil. Sintesis sol gel merupakan metode sintesis nanopartikel dengan menggunakan dua tahapan fase yaitu sol dan gel. Sol merupakan suatu suspensi koloid dimana fasa terdispersinya berupa zat padat dan pendispersinya berupa zat cair. Sedangkan gel merupakan suatu zat yang memiliki jaringan kontinu dalam tiga dimensi yang terbentuk dari rantai polimer. Metode sol gel akan menghasilkan suatu material berupa keramik dan gelas. Dengan menggunakan metode sol gel maka akan memungkinkan membentuk ukuran partikel skala nano sekaligus membentuk penampakan morfologi yang homogen. Hal inilah yang melatarbelakangi penelitian ini menggunakan metode sol gel untuk memperoleh silika yang terkandung dalam zeolit alam Lampung (Liza et al., 2018).

Sintesis $\mathrm{SiO}_{2}$ dapat dilakukan dengan beberapa metode, diantaranya yaitu dengan metode sol gel dan leaching. Sintesis $\mathrm{SiO}_{2}$ menggunakan metode sol gel dan leaching berpengaruh terhadap luas permukaan partikel silika, dimana metode sol gel memiliki luas permukaan yang lebih tinggi dari pada metode leaching. Menurut riset yang sama juga menyebutkan bahwa metode sol-gel akan selalu menghasilkan silika berbentuk gel dengan struktur kristal amorf. Hal ini dikarenakan $\mathrm{NaOH}$ hanya dapat melarutkan silika amorf, yang kemudian diendapkan. Berbeda dengan metode leaching dimana leachate tidak bereaksi dengan silika pada sampel, sehingga silika yang dapat dihasilkan dari leaching berbentuk bubuk dengan struktur kristal amorf, quartz, dan crystoballite sesuai dengan suhu pembakarannya (Fernandes et al., 2017).

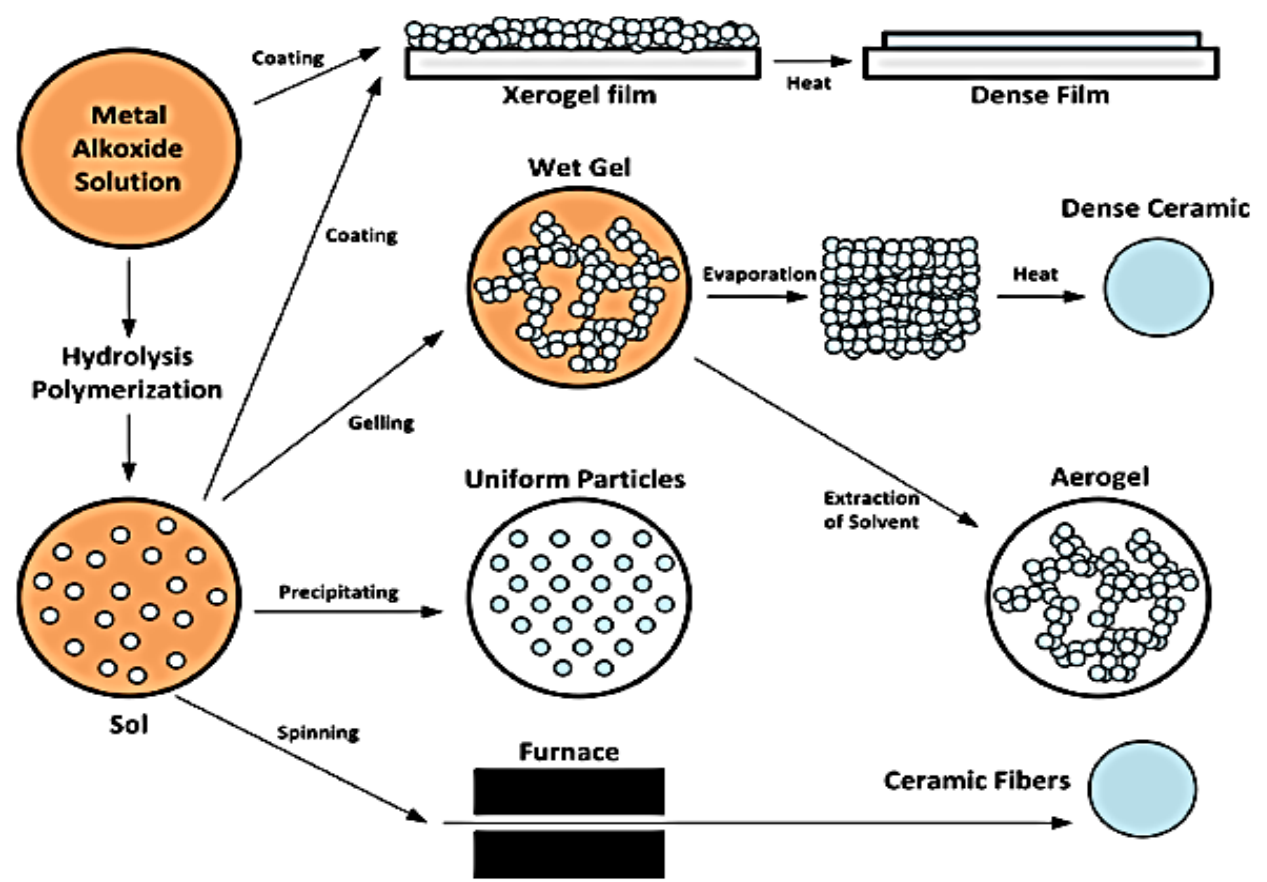

Gambar 1.Skematik proses sol gel (Trindade dan Politi, 2019)

Zeolit sintetis lebih sering digunakan untuk kepentingan komersial dibandingkan dengan zeolit alam, hal ini dikarenakan keseragaman ukuran partikel dan tingkat kemurnian 
yang tinggi pada zeolit sintetis. Sebagai contoh penggunaan zeolit sintetis di dalam aplikasiaplikasi khusus seperti katalis zeolit HZSM-5 untuk produksi biofuel (Al-Muttaqii, M. et al., 2019a, Al-Muttaqii, M. et al., 2019b, Al Muttaqii, M. et al., 2017, Al Muttaqii, M. et al., 2021). Pengetahuan yang sangat luas dari bahan berbasis silika nanopori telah diteliti sejak awal 1990 -an menampilkan luas permukaan yang bisa melebihi $1000 \mathrm{~m}^{2} / \mathrm{g}$ dengan total volume pori lebih besar dari $1 \mathrm{~cm}^{3} / \mathrm{g}$. Prekursor silika yang biasa digunakan adalah silikon alkoksida. Reaktan oksida logam menghidrolisis dan memadat melalui kimia sol gel untuk membentuk jaringan siloksan atau organosiloksan, seringkali dalam kondisi hidrotermal. Biasanya asam atau basa digunakan untuk mengkatalisis hidrolisis dan kondensasi sol gel. Pada pH basa yang berada di atas titik isoelektrik silika $(\mathrm{pH} 2)$, spesies silika akan menjadi anionik dan dapat berasosiasi kuat dengan molekul surfaktan yang memiliki gugus kepala kationik. Pendekatan sintetik umum adalah dengan menggunakan molekul surfaktan dalam larutan yang berkumpul menjadi misel atau di atas konsentrasi kritis misel. Misel berinteraksi dengan prekursor silika untuk membentuk nanokomposit sol gel surfaktan yang tersusun atau semiterurut. Pengisi ruang surfaktan dihilangkan dengan kalsinasi atau dengan ekstraksi berbasis pelarut untuk menghasilkan produk nanoporous. Mekanisme kristal cair awalnya diusulkan untuk menjelaskan sintesis silika mesopori dan tetap berguna ketika mengilustrasikan mekanisme (Glover et al., 2020).

Silika gel adalah butiran seperti kaca dengan bentuk yang sangat berpori, silika dibuat secara sintetis dari natrium silikat. Walaupun namanya gel, namun gel silika berbentuk padat. Silika gel merupakan suatu bentuk dari silika yang dihasilkan melalui penggumpalan sol natrium silikat $\left(\mathrm{NaSiO}_{2}\right)$. Sol mirip agar-agar ini dapat didehidrasi sehingga berubah menjadi padatan atau butiran mirip kaca yang bersifat tidak elastis. Silika gel sebagai adsorben, telah dikenal luas dalam dunia kimia. Struktur polimernya yang amorf (tidak tertata), gabungan dari agregat-agregat $\mathrm{Si}-\mathrm{OH}$ yang membentuk polimer terarah $\mathrm{Si}-\mathrm{O}-\mathrm{Si}$, menjadikan senyawa adsorben ini memiliki kestabilan yang cukup baik. Silika gel memiliki kelembaban untuk pencegahan penjamuran, karat didalam kondisi kedap udara, secara bersamaan dapat menyerap kelembaban itu sendiri karena perubahan suhu. Selain itu, silika gel digunakan sebagai kemasan, yang secara luas digunakan dalam instrumen presisi, kulit, sepatu, pakaian, makanan, obat-obatan dan peralatan listrik rumah tangga dan sebagainya (Meriatna et al., 2015). Produk silika bersifat mesopori kombinasi dari mikropori atau makropori dengan ukuran pori $10 \mathrm{~nm}$ (Glover et al., 2020).

Pada penelitian ini akan dilakukan analisa pengaruh variasi konsentrasi larutan $\mathrm{NaOH}$ dan massa zeolit alam Lampung terhadap produk silika yang dihasilkan dengan menggunakan metode sol gel dan terhadap komposisi dan fasa yang terbentuk pada produk silika.

\section{METODE PENELITIAN Alat dan Bahan}

Alat yang digunakan dalam penelitian ini yaitu ball mill, oven, gelas beaker, hot plate, kertas $\mathrm{pH}$, kertas saring whatmann No. 41, mortar dan pastel, timbangan digital, sedangkan karakterisasi sampel menggunakan X-Ray Diffraction (XRD, PANalytical X'Pert3) dan X-Ray Fluorescence (XRF, Epsilon ${ }^{3 \mathrm{LLE}}$ ).

Bahan yang digunakan dalam penelitian ini yaitu zeolit alam Lampung yang digunakan berasal dari Sidomulyo Kalianda, Lampung Selatan. $\mathrm{NaOH}$ p.a (pro analysis) dan $\mathrm{HCl} 37 \%$ p.a (pro analysis) dari E-Merck Jerman.

\section{Preparasi Zeolit Alam}

Metode preparasi sampel pada penelitian ini mengikuti penelitan sebelumnya (Al

\section{Syafriadi, Siti Marhamah, Muhammad Al Muttaqii}

396 Pengaruh Variasi Konsentrasi Naoh Pada Zeolit Alam Lampung Terhadap Produk Silika 
Muttaqii, M. et al., 2019, Al Muttaqii, M. et al., 2021) yaitu menyiapkan zeolit alam Lampung, kemudian dihaluskan menggunakan ball mill selama 3 jam. Setelah melalui proses ball mill, zeolit dikeringkan dengan menggunakan oven pada suhu $130^{\circ} \mathrm{C}$ selama 5 jam. Zeolit yang telah dikeringkan kemudian diayak mesh 200. Tahap pertama, zeolit dimasukkan kedalam larutan $\mathrm{HCl} 1 \mathrm{M} 250 \mathrm{ml}$ dan dipanaskan pada suhu $110{ }^{\circ} \mathrm{C}$, diaduk selama 1 jam. Selanjutnya, zeolit dicuci sampai $\mathrm{pH}$ netral $(\mathrm{pH}=7)$ dan dikeringkan pada suhu $130{ }^{\circ} \mathrm{C}$ selama 3 jam. Kemudian, membuat larutan $\mathrm{NaOH} 100 \mathrm{ml}$ dengan variasi konsentrasi $(0,2,0,4,0,6$, $0,8,1) \mathrm{M}$, dan variasi massa zeolit $(15,30,45) \mathrm{gr}$.

Zeolit yang telah divariasi massa dimasukkan kedalam larutan $\mathrm{NaOH}$ dipanaskan pada suhu $70{ }^{\circ} \mathrm{C}$, dan diaduk selama 5 jam. Setelah dipanaskan, larutan $\mathrm{NaOH}$ yang telah tercampur dengan zeolit kemudian didinginkan, dan ditutup dengan plastik wrapp. Ini bertujuan untuk menjaga sampel yang telah dibuat tanpa ada material atau zat-zat yang lain yang masuk. Lalu di-aging selama 24 jam. Zeolit dipisahkan dengan cairan (filtrat) dengan menggunakan kertas saring untuk memperoleh sol zeolit alam Lampung. Kemudian, menambahkan larutan $\mathrm{HCl} 1 \mathrm{M}$ pada sol zeolit alam Lampung hingga netral $(\mathrm{pH}=7)$. Setelah $\mathrm{pH}$ netral maka diperoleh gel silika dan di-aging selama 24 jam. Silika serbuk digerus dengan menggunakan mortar dan pastel hingga halus kemudian diayak (mesh 270). Serbuk zeolit alam Lampung, residu dan silika yang telah didapatkan kemudian dikarakterisasi menggunakan X-Ray Diffraction (XRD) dan X-Ray Fluorescence (XRF).

\section{Karakterisasi Zeolit Alam}

Hasil karakterisasi sampel silika dikarakterisasi menggunakan $X$-Ray Diffraction (XRD, PANalytical X'Pert3) untuk menentukan struktur kristal dan fasa yang terbentuk, dan X-Ray Fluorescence (XRF, Epsilon ${ }^{3 \mathrm{XLE}}$ ) untuk menentukan komposisi kimia yang terkandung.

\section{HASIL DAN PEMBAHASAN}

Pada penelitian ini zeolit alam yang digunakan berasal dari daerah Sidomulyo, Kalianda Lampung Selatan. Zeolit alam diaktivasi secara kimia. Pemurnian silika dari zeolit alam menggunakan metode sol gel. Hasil karakterisasi sampel silika menggunakan $X$-Ray Diffraction (XRD) dibahas untuk menentukan struktur kristal dan fasa yang terbentuk, $X$-Ray Fluorescence (XRF) untuk menentukan komposisi kimia yang terkandung.

\section{Pengaruh Variasi Konsentrasi Larutan NaOH Terhadap Produk Silika}

Penelitian yang dilakukan menggunakan variasi konsentrasi $\mathrm{NaOH}(0,2,0,4,0,6,0,8$, 1) $M$ dan variasi massa di setiap sampel zeolit alam untuk memperoleh produk silika. Produk silika konsentrasi $\mathrm{NaOH} 0,2 \mathrm{M}$ sebesar $(88,757,69,352,76,073) \%$, produk silika konsentrasi $\mathrm{NaOH} 0,4 \mathrm{M}$ sebesar $(90,884,79,556,71,717) \%$, produk silika konsentrasi $\mathrm{NaOH} 0,6 \mathrm{M}$ sebesar $(97,233,84,170,77,072) \%$, produk silika konsentrasi $\mathrm{NaOH} \mathrm{0,8} \mathrm{M} \mathrm{sebesar}(97,341$, 92,276, 87,198) \% dan produk silika konsentrasi $\mathrm{NaOH} 1 \mathrm{M}$ sebesar $(97,738,95,350$, $93,373) \%$. Pengaruh variasi konsentrasi $\mathrm{NaOH}(0,2,0,4,0,6,0,8,) \mathrm{M}$ terhadap produk silika yang dihasilkan ditunjukkan pada Gambar 2. 


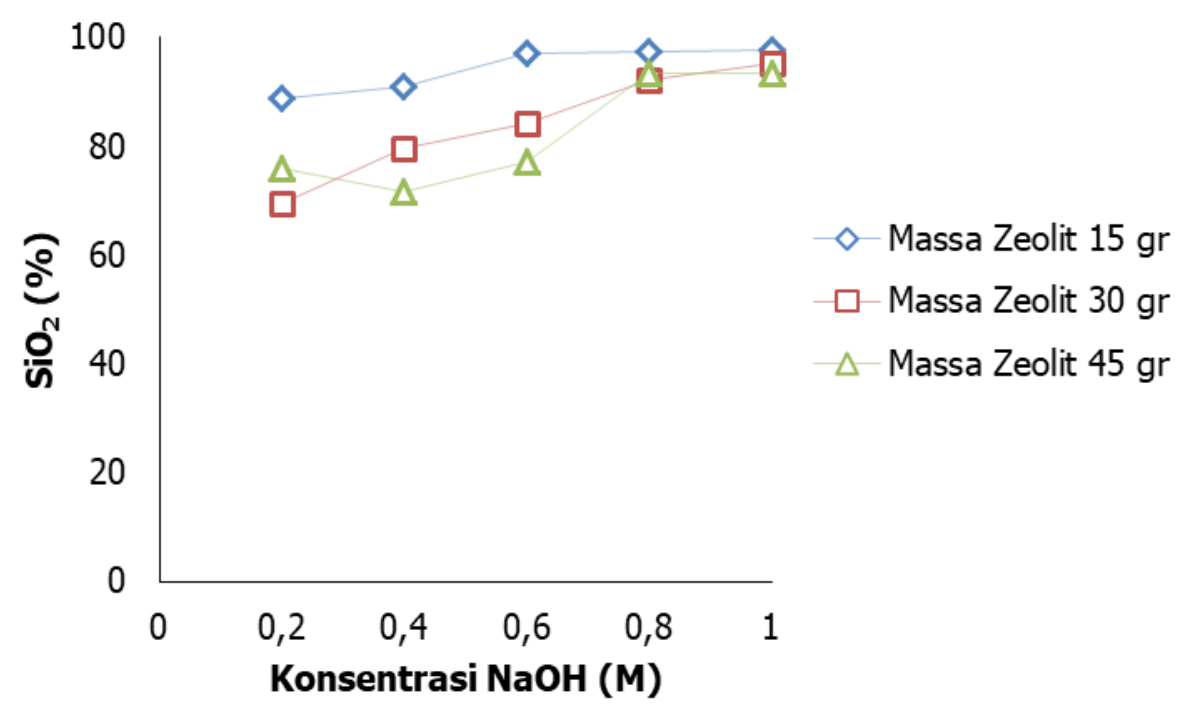

Gambar 2. Grafik pengaruh konsentrasi $\mathrm{NaOH}$ terhadap produk silika.

Berdasarkan Gambar 2, larutan $\mathrm{NaOH}$ dalam reaksi campuran bertindak sebagai aktivator di dalam pelarutan garam silikat dan alumina. Semakin besar konsentrasi $\mathrm{NaOH}$ yang diberikan maka silika yang diproleh akan bertambah. Pada konsentrasi $\mathrm{NaOH} 0.4 \mathrm{M}$ terjadi penurunan dalam perolehan silika sebesar 71,717 \%. Hal tersebut terjadi karena $\mathrm{NaOH}$ tidak hanya bereaksi dengan silika saja, tetapi juga bereaksi dengan senyawa lain seperti $\mathrm{Al}_{2} \mathrm{O}_{3}$ yang dapat ikut larut. Hasil perolehan produk silika terbaik didapat pada variasi konsentrasi $\mathrm{NaOH} 1 \mathrm{M}$ sebesar 97,738\% dengan massa zeolit 15 gr. Perlakuan $\mathrm{NaOH}$ ini menyebabkan peningkatan kapasitas adsorpsi sehingga variasi massa berpengaruh dalam perolehan silika. Semakin banyak massa zeolit yang digunakan maka akan semakin sedikit silika yang diperoleh, dikarenakan filtrat yang terabsorpsi. Hal ini dibuktikan pada variasi massa zeolit alam $30 \mathrm{gr}$ dan $45 \mathrm{gr}$, silika yang dihasilkan semakin berkurang dibandingkan pada variasi massa zeolit alam $15 \mathrm{gr}$.

\section{Pengaruh Variasi Konsentrasi Larutan $\mathrm{NaOH}$ dan Variasi Massa Zeolit Alam Terhadap Senyawa Kimia}

Tabel 2, 3, dan 4 menunjukkan komposisi kimia pada produk silika yang diperoleh dari variasi massa zeolit dan larutan $\mathrm{NaOH}$. Hasil karakterisasi sampel bubuk silika menggunakan XRF yang diperoleh dari variasi zeolit alam $15 \mathrm{gr}$ dengan $\mathrm{NaOH} \mathrm{0,2} \mathrm{M} \mathrm{(Z1),} \mathrm{0,4} \mathrm{M} \mathrm{(Z2),} \mathrm{0,6} \mathrm{M}$ (Z3), $1 \mathrm{M}$ (Z5) ditunjukkan pada Tabel 2. Variasi zeolit alam $30 \mathrm{gr}$ dengan $\mathrm{NaOH} \mathrm{0,2} \mathrm{M} \mathrm{(Z6),}$ 0,4 M (Z7), 0,6 M (Z8), 0,8 M (Z9), dan $1 \mathrm{M}$ (Z10) ditunjukkan pada Tabel 3. Variasi zeolit alam 45 gr dengan $\mathrm{NaOH}$ 0,2 M (Z11), 0,4 M (Z12), 0,6 M (Z13), 0,8 M (Z14), dan $1 \mathrm{M}$ (Z15) ditunjukkan pada Tabel 4. Berdasarkan Tabel 2-4, dapat dilihat bahwa kandungan $\mathrm{SiO}_{2}$ terbanyak diperoleh pada variasi massa zeolit $15 \mathrm{gr}$ dan larutan $\mathrm{NaOH} 1 \mathrm{M}$ sebesar $97,738 \%$. Sedangkan pada massa zeolit $30 \mathrm{gr}$ dengan $\mathrm{NaOH} 1 \mathrm{M}(\mathrm{Z10})$ dan massa zeolit $45 \mathrm{gr}$ dengan $\mathrm{NaOH} 1 \mathrm{M}$ (Z15) diperoleh masing-masing sebesar 95,350\% dan 93,373\%. Hal ini juga menunjukkan bahwa zeolit alam merupakan salah satu sumber mineral yang melimpah dan mudah didapatkan untuk menghasilkan silika. 
Tabel 2. Hasil karakterisasi XRF sampel bubuk silika Z1, Z2, Z3, Z4 dan Z5.

\begin{tabular}{cccccc}
\hline Senyawa & \multicolumn{5}{c}{ Konsentrasi (\%) } \\
\cline { 2 - 6 } Oksida & $\mathrm{Z1}$ & $\mathrm{Z2}$ & $\mathrm{Z3}$ & $\mathrm{Z4}$ & $\mathrm{Z} 5$ \\
\hline $\mathrm{Al}_{2} \mathrm{O}_{3}$ & 4,481 & 2,581 & - & 0,663 & - \\
$\mathrm{SiO}_{2}$ & 88,757 & 90,884 & 97,233 & 97,341 & 97,738 \\
$\mathrm{P}_{2} \mathrm{O}_{5}$ & 0,965 & 0,917 & 0,952 & 0,944 & 0,933 \\
$\mathrm{~K}_{2} \mathrm{O}$ & 0,846 & 1,442 & 0,596 & 0,494 & 0,706 \\
$\mathrm{CaO}$ & 0,697 & 1,273 & 0,699 & 0,381 & 0,439 \\
$\mathrm{TiO}_{2}$ & 0,239 & 0,181 & - & - & - \\
$\mathrm{Fe}_{2} \mathrm{O}_{3}$ & 3,664 & 2,605 & 0,420 & 0,124 & 0,102 \\
$\mathrm{ZnO}$ & 0,269 & - & - & - & - \\
\hline
\end{tabular}

Tabel 3. Hasil karakterisasi XRF sampel bubuk silika Z6, Z7, Z8, Z9 dan Z10.

\begin{tabular}{cccccc}
\hline Senyawa & \multicolumn{5}{c}{ Konsentrasi (\%) } \\
\cline { 2 - 6 } Oksida & $\mathrm{Z6}$ & $\mathrm{Z} 7$ & $\mathrm{Z} 8$ & $\mathrm{Z} 9$ & $\mathrm{Z} 10$ \\
\hline $\mathrm{Al}_{2} \mathrm{O}_{3}$ & 13,493 & 10,200 & 7,246 & 1,852 & 1,786 \\
$\mathrm{SiO}_{2}$ & 69,352 & 79,556 & 84,170 & 92,276 & 95,350 \\
$\mathrm{P}_{2} \mathrm{O}_{5}$ & 0,930 & 0,879 & 0,903 & 0,955 & 0,890 \\
$\mathrm{~K}_{2} \mathrm{O}$ & 0,988 & 1,137 & 1,295 & 1,404 & 0,621 \\
$\mathrm{CaO}$ & 1,368 & 0,965 & 1,305 & 1,043 & 0,580 \\
$\mathrm{TiO}_{2}$ & 0,474 & 0,266 & 0,212 & 0,144 & - \\
$\mathrm{Fe}_{2} \mathrm{O}_{3}$ & 13,029 & 6,772 & 4,729 & 1,907 & 0,687 \\
$\mathrm{ZnO}$ & 0,116 & - & - & 0,336 & - \\
\hline
\end{tabular}

Tabel 4. Hasil karakterisasi XRF sampel bubuk silika Z11, Z12, Z13, Z14 dan Z15.

\begin{tabular}{cccccc}
\hline Senyawa & \multicolumn{5}{c}{ Konsentrasi (\%) } \\
\cline { 2 - 6 } $\mathrm{Oksida}$ & $\mathrm{Z11}$ & $\mathrm{Z12}$ & $\mathrm{Z13}$ & $\mathrm{Z14}$ & $\mathrm{Z15}$ \\
\hline $\mathrm{Al}_{2} \mathrm{O}_{3}$ & 10,047 & 13,355 & 6,625 & 4,577 & 1,657 \\
$\mathrm{SiO}_{2}$ & 76,073 & 71,717 & 77,072 & 87,198 & 93,373 \\
$\mathrm{P}_{2} \mathrm{O}_{5}$ & 0,915 & 0,871 & 0,952 & 0,908 & 0,892 \\
$\mathrm{~K}_{2} \mathrm{O}$ & 2,142 & 2,904 & 2,954 & 1,756 & 1,195 \\
$\mathrm{CaO}$ & 1,885 & 2,376 & 1,703 & 1,251 & 0,777 \\
$\mathrm{TiO}_{2}$ & 0,411 & 0,419 & 0,449 & 0,233 & 0,120 \\
$\mathrm{Fe}_{2} \mathrm{O}_{3}$ & 8,023 & 8,069 & 9,885 & 3,934 & 1,897 \\
$\mathrm{ZnO}$ & - & - & - & - & - \\
$\mathrm{MgO}$ & 0,204 & - & - & - & - \\
\hline
\end{tabular}

\section{Pengaruh Variasi Konsentrasi Larutan NaOH dan Variasi Massa Zeolit Alam Terhadap Fasa Pada Produk Silika}

Produk silika yang dihasilkan dikarakterisasi dengan XRD bertujuan untuk mengetahui fasa yang terbentuk. Gambar 4-6 menunjukkan difraktogram silika dengan variasi massa zeolit alam 15, 30, dan 45 gr. Gambar 4 menunjukkan puncak yang terbentuk berbentuk amorf. Pada puncak $2 \theta=30,5419^{\circ}$ diperoleh fasa baru yaitu stishovite $\left(\mathrm{Si}_{2.00} \mathrm{O}_{4.00}\right)$ dengan ref.code COD 96-900-1282. Gambar 5 dan Gambar 6 juga menunjukkan hasil yang sama, dimana semua produk silika yang dihasilkan menunjukkan bentuk amorf. Pengaruh variasi konsentrasi $\mathrm{NaOH}$ dan massa zeolit terhadap komposisi senyawa kimia silika mneunjukkan semakin besar konsentrasi $\mathrm{NaOH}$ yang digunakan maka akan meningkatkan perolehan silika, namun semakin besar massa zeolit alam yang digunakan maka akan menurunkan perolehan silika. Pengaruh variasi konsentrasi $\mathrm{NaOH}$ dan massa zeolit terhadap fasa yang terbentuk pada silika menunjukkan silika yang diperoleh didominasi oleh fasa tridymite $\left(\mathrm{Si}_{24.00} \mathrm{O}_{48.00}\right)$, Cristobalite $\left(\mathrm{Si}_{4.00} \mathrm{O}_{8.00}\right)$, Coesite $\left(\mathrm{Si}_{16.00} \mathrm{O}_{32.00}\right)$, Moganite $\left(\mathrm{Si}_{12.00} \mathrm{O}_{24.00}\right)$, Quartz $\left(\mathrm{Si}_{3.00} \mathrm{O}_{6.00}\right)$ dan Stishovite $\left(\mathrm{Si}_{2.00} \mathrm{O}_{4.00}\right)$. 


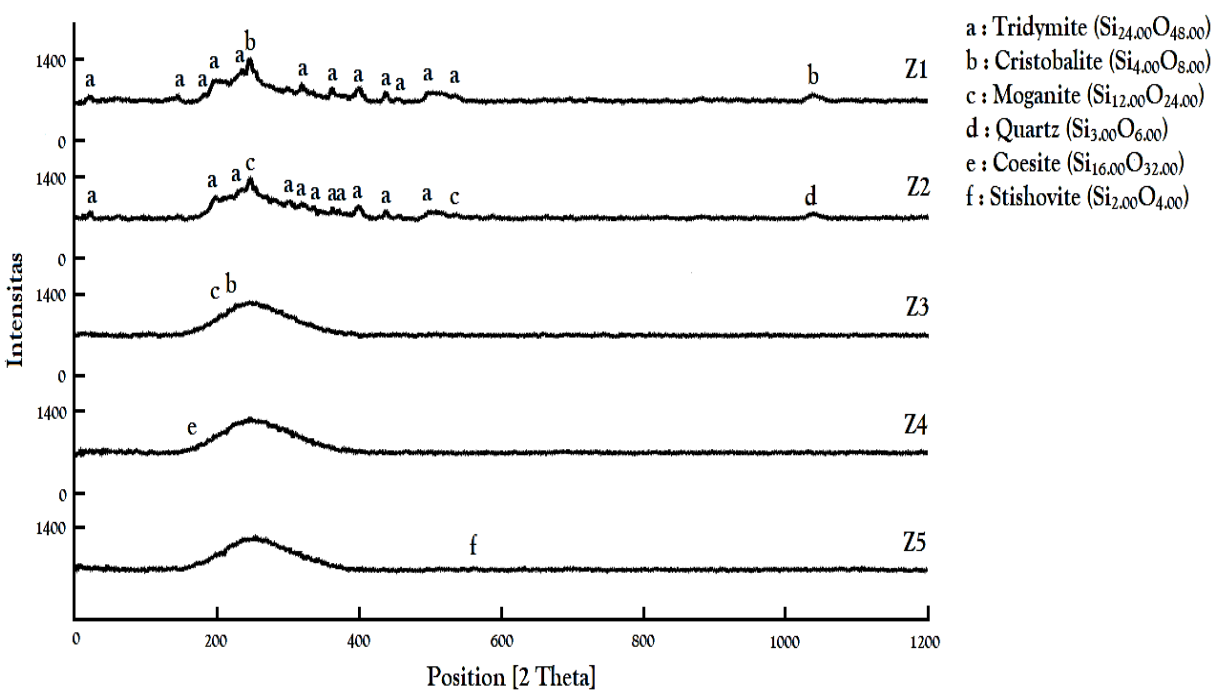

Gambar 4. Difraktogram silika dengan variasi massa zeolite alam $15 \mathrm{gr}$.

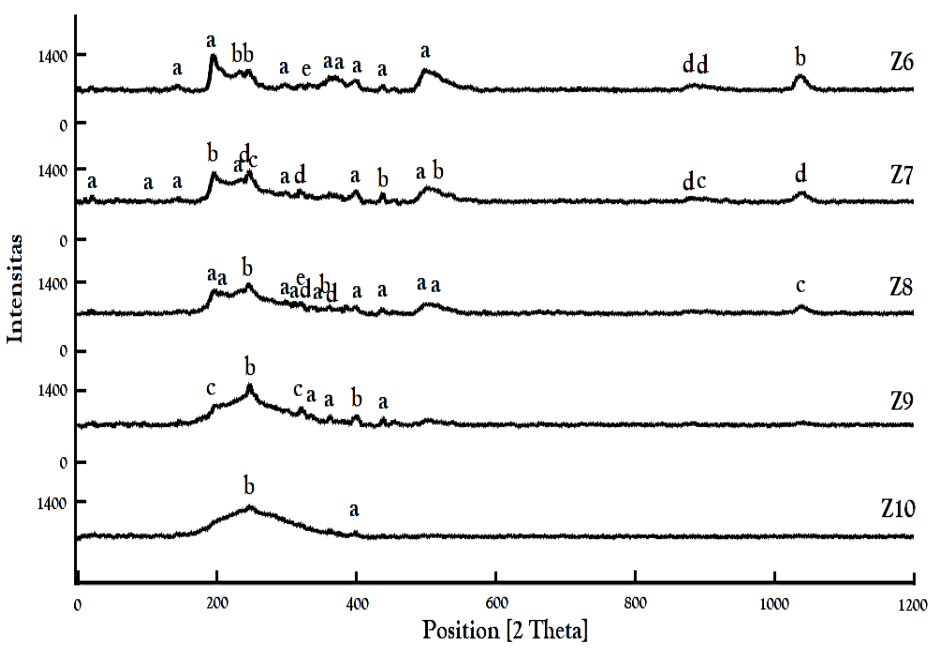

a : Tridymite $\left(\mathrm{Si}_{24.00} \mathrm{O}_{48.00}\right)$ $\mathrm{b}$ : Cristobalite $\left(\mathrm{Si}_{400} \mathrm{O}_{8.00}\right)$ c: Moganite $\left(\mathrm{Si}_{12.00} \mathrm{O}_{24.00}\right)$ d: Coesite $\left(\mathrm{Si}_{16.00} \mathrm{O}_{32.00}\right)$ e : Quartz $\left(\mathrm{Si}_{3.00} \mathrm{O}_{6.00}\right)$

Gambar 5. Difraktogram silika dengan variasi massa zeolite alam $30 \mathrm{gr}$.

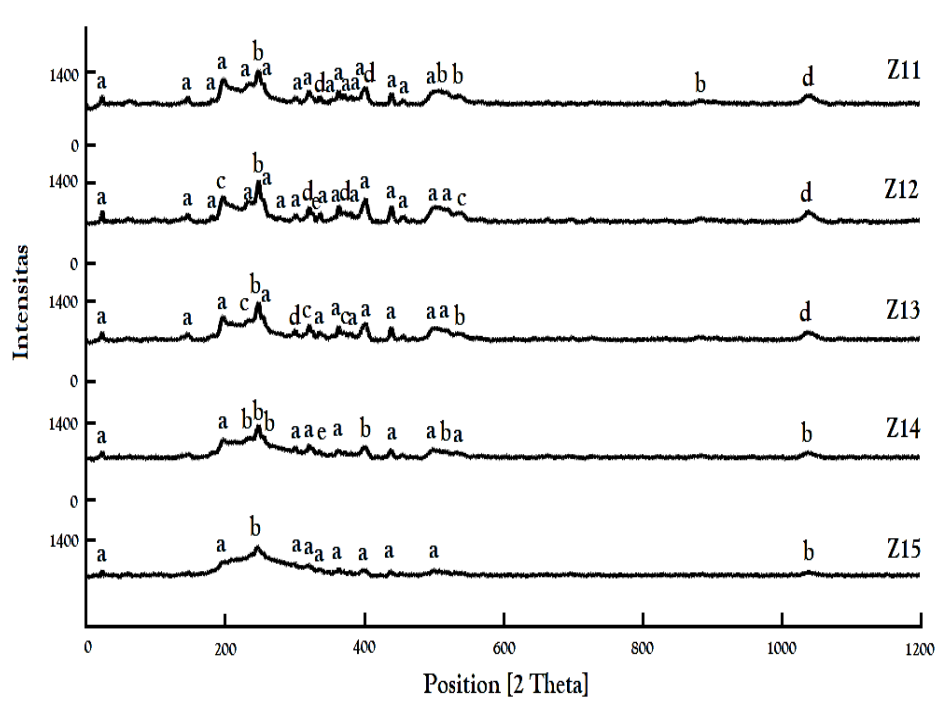

a : Tridymite $\left(\mathrm{Si}_{24.00} \mathrm{O}_{48.00}\right)$ $\mathrm{b}$ : Cristobalite $\left(\mathrm{Si}_{4,00} \mathrm{O}_{8,00}\right)$ c : Moganite $\left(\mathrm{Si}_{12,00} \mathrm{O}_{24,00}\right)$ d : Coesite $\left(\mathrm{Si}_{16.00} \mathrm{O}_{32.00}\right)$ e : Quartz $\left(\mathrm{Si}_{3,00} \mathrm{O}_{6.00}\right)$

Gambar 6. Difraktogram silika dengan variasi massa zeolite alam $45 \mathrm{gr}$. 


\section{KESIMPULAN}

Variasi konsentrasi $\mathrm{NaOH}$ dengan zeolit alam menunjukkan silika yang diperoleh semakin meningkat dengan meningkatnya konsentrasi $\mathrm{NaOH}$ dari 0,2 $\mathrm{M}, 0,4 \mathrm{M}, 0,6 \mathrm{M}, 0,8 \mathrm{M}$, dan $1 \mathrm{M}$. Hasil terbaik produk silika diperoleh pada variasi konsentrasi $\mathrm{NaOH} 1 \mathrm{M}$ dengan massa zeolit $15 \mathrm{gr}$ sebesar 97,738 \%. Pengaruh variasi konsentrasi $\mathrm{NaOH}$ dan variasi massa zeolit alam Lampung terhadap kandungan senyawa kimia dalam setiap produk silika didominasi kandungan $\mathrm{SiO}_{2}$ dan berbentuk amorf. Hasil Analisa XRD menunjukkan fasa yang terbentuk pada produk silika didominasi oleh fasa tridymite $\left(\mathrm{Si}_{24.00} \mathrm{O}_{48.00}\right)$, Cristobalite $\left(\mathrm{Si}_{4.00} \mathrm{O}_{8.00}\right)$, Coesite $\left(\mathrm{Si}_{16.00} \mathrm{O}_{32.00}\right)$, Moganite $\left(\mathrm{Si}_{12.00} \mathrm{O}_{24.00}\right)$, Quartz $\left(\mathrm{Si}_{3.00} \mathrm{O}_{6.00}\right)$ dan Stishovite $\left(\mathrm{Si}_{2.00} \mathrm{O}_{4.00}\right)$.

\section{UCAPAN TERIMAKASIH}

Penulis mengucapkan terima kasih kepada Kementrian Ristek Dikti atas pendanaan penelitian ini melalui program Insensif Riset Sistem Inovasi Nasional (INSINAS) dengan nomor kontrak No.12/INS/PPK/E4/2021. Terima kasih kepada Balai Penelitian Teknologi Mineral Lembaga Ilmu Pengetahuan Indonesia yang telah mengizinkan kami dalam pelaksanaan penelitian ini.

\section{KONTRIBUSI PENULIS}

Muhammad Al Muttaqii merupakan kontributor utama didalam penulisan ini. Syafriadi, Siti Marhamah, Hendris Hendarsyah Kurniawan, dan Novita Ariani merupakan kontributor anggota. MAM menginterpretasikan data, informasi lain, dan menyusun artikel. S, SM, HHK, dan NA menguji sampel, melakukan pengeditan, dan penambahan analisis.

\section{DAFTAR PUSTAKA}

Al-Muttaqii, M. et al. (2019a) 'Bio-kerosene and bio-gasoil from coconut oils via hydrocracking process over Ni-Fe/HZSM-5 catalyst', Bulletin of Chemical Reaction Engineering \&amp;amp; Catalysis, 14(2), pp. 309-319. doi: 10.9767/bcrec. 14.2.2669.309-319.

Al-Muttaqii, M. et al. (2019b) 'Hydrocracking of coconut oil over Ni-Fe/HZSM-5 catalyst to produce hydrocarbon biofuel', Indonesian Journal of Chemistry, 19(2), pp. 319-327. doi: 10.22146/ijc.33590.

Al Muttaqii, M. et al. (2017) 'Co-Ni/HZSM-5 Catalyst for Hydrocracking of Sunan Candlenut Oil (Reutealis trisperma (Blanco) Airy Shaw) for Production of Biofuel', The Journal of Pure and Applied Chemistry Research, 6(2), pp. 84-92. doi: 10.21776/ub.jpacr.2017.006.02.257.

Al Muttaqii, M. et al. (2019) 'Pengaruh Aktivasi secara Kimia menggunakan Larutan Asam dan Basa terhadap Karakteristik Zeolit Alam', Jurnal Riset Teknologi Industri, 13(2), p. 266. doi: 10.26578/jiti.v13i2.5577.

Al Muttaqii, M. et al. (2021) 'Hydrocracking process of coconut oil using Ni-Zn/HZSM-5 catalyst for hydrocarbon biofuel production', Journal of Physics: Conference Series, 1725(1). doi: 10.1088/1742-6596/1725/1/012008.

Al Muttaqii, M. et al. (2021) 'Production of biodiesel over $\mathrm{ZnO}^{-\mathrm{TiO}_{2}}$ bifunctional oxide catalyst supported on natural zeolite Production of biodiesel over ZnO-TiO 2 bifunctional oxide catalyst supported on natural zeolite', pp. 4-10. doi: 10.1088/17551315/926/1/012083.

Ates, A. (2018) 'Effect of alkali-treatment on the characteristics of natural zeolits with different compositions', Journal of Colloid and Interface Science, 523(March), pp. 266281. doi: 10.1016/j.jcis.2018.03.115. 
Dur, S. (2017) 'Zeolit Processing As Heavy Material', ZERO: Jurnal Sains, Matematika dan Terapan, 1(1), pp. 33-45. doi: 10.30829/zero.v1i1.1457.

Fernandes, I. J. et al. (2017) 'Characterization of silica produced from rice husk ash: Comparison of purification and processing methods', Materials Research, 20, pp. 519525. doi: 10.1590/1980-5373-mr-2016-1043.

Ginting, et al.(2019) 'Journal of Chemical Process Engineering Sintesis Zeolit Lynde Type-A ( LTA ) Dari Zeolit Alam Lampung ( Zal )', 4(2655).

Glover, T. G., Melde, B. J. and Johnson, B. J. (2020) 'Nanoporous silicas and their composites, Nanoporous Materials for Molecule Separation and Conversion',INC. doi: 10.1016/b978-0-12-818487-5.00004-2.

Liza, Y. M. et al. (2018) 'Gelation Sol- Gel Proces s Densification Ageing Drying', Pendidikan FMIPA Universitas Negeri Padang.

Meriatna et al. (2015) 'Pengaruh Temperatur Pengeringan dan Konsentrasi Asam Sitrat Pada Pembuatan Silika Gel Dari Sekam Padi', Jurnal Teknologi Kimia Unimal, 4(1), pp. 7888. doi: 10.1002/anie.201308264.

Pratomo, S. W., Mahatmanti, F. W. and Sulistyaningsih, T. (2017) 'Pemanfaatan Zeolit Alam Teraktivasi H 3 PO 4 sebagai Adsorben Ion Logam Cd ( Ii ) dalam Larutan', Indonesian Journal of Chemical Science, 6(2), pp. 161-167.

Purnamasari, E. N. (2015) 'Efektivitas Zeolit Alam Sebagai AdsorbentDalam Pengolahan Air Limbah YangMengandung Alkyl Benzene Sulfonat (Las)', Jurnal Media Teknik, 12(1), pp. 48-58.

Sugiarti, S., Charlena, C. and Aflakhah, N. A. (2017) 'Zeolit Sintetis Terfungsionalisasi 3(Trimetoksisilil)-1-Propantiol sebagai Adsorben Kation Cu(II) dan Biru Metilena', Jurnal Kimia VALENSI, 3(1), pp. 11-19. doi: 10.15408/jkv.v3i1.5144.

Trindade, F. and Politi, M. J. (2019) Sol-Gel Chemistry-Deals With Sol-Gel Processes, Nano Design for Smart Gels. Elsevier Inc. doi: 10.1016/B978-0-12-814825-9.00002-3.

Wang, C. et al. (2019) 'Quantitative arrangement of Si/Al ratio of natural zeolit using acid treatment', Applied Surface Science. Elsevier, 498(May), p. 143874. doi: 10.1016/j.apsusc.2019.143874. 